\title{
Praktyczne problemy działania polskiego systemu alternatywnego dochodzenia roszczeń pacjentów z tytułu zdarzeń medycznych
}

Alternatywny system dochodzenia roszczeń pacjentów z tytułu zdarzeń medycznych funkcjonuje w Polsce już od 8 lat. Z jego wprowadzeniem wiqzały się wysokie oczekiwania, m.in. w zakresie zwiększenia skuteczności i szybkości dochodzenia roszczeń przez pacjentów oraz odciq̨żenia sqdownictwa. W niniejszym artykule, w celu skonfrontowania założeń z rzeczywistościq, analizie poddane zostały dane dotyczace funkcjonowania systemu od poczqtku jego istnienia. Wyniki analizy wskazuja, że system nie funkcjonuje na satysfakcjonujacym poziomie i nie spełnia założeń jego implementacji.

Słowa kluczowe: zdarzenie medyczne, prawa pacjenta, wojewódzkie komisje do spraw orzekania o zdarzeniach medycznych.

\section{Wprowadzenie}

Roszczenia związane ze szkodami wyrządzonymi podczas zabiegów medycznych stanowia jedne z najtrudniejszych do wyegzekwowania przez poszkodowanych ze względu na trudności w wykazaniu winy i związku przyczynowego pomiędzy zdarzeniem a szkoda, problemami z uzyskaniem odpowiednich środków dowodowych oraz wysokimi kosztami ewentualnego sporu sądowego. Zgodnie z danymi Ministerstwa Sprawiedliwości czynniki te powodują, że sprawy dotyczące błędów medycznych trwają znacznie dłużej niż pozostałe sprawy o odszkodowanie - nawet dziesięć lat w porównaniu do czterech $^{1}$. Sytuacja prawna osób poszkodowanych ulega stopniowej poprawie, m.in. dlatego że w drugiej połowie XX wieku na świecie nasiliły się krytyka modelu tradycyjnego oraz tendencja do wprowadzenia alternatywnych rozwiązań w zakresie

1. Uzasadnienie do rządowego projektu ustawy o zmianie ustawy o prawach pacjenta i Rzeczniku Praw Pacjenta oraz niektórych innych ustaw, VI Kadencja, druk sejm. nr 3488, s. 2. 
naprawy szkód wyrzạdzonych w związku z błędami medycznymi². Polski system funkcjonuje już dziewiąty rok, w związku z czym warto przeanalizować jego działanie, w szczególności ze względu na jego efektywność, skrócenie czasu potrzebnego na uzyskanie odszkodowania i wysokość uzyskiwanych odszkodowań. Ocena została przeprowadzona w drodze zebrania i analizy danych ilościowych uzyskanych od Rzecznika Praw Pacjenta oraz danych statystycznych udostępnionych przez Naczelną Izbę Kontroli i Ministerstwo Sprawiedliwości. Dla lepszego zrozumienia wyników przeprowadzonych badań warto najpierw krótko przybliżyć tematykę zdarzeń medycznych oraz założeń systemu alternatywnego dochodzenia roszczeń w Polsce.

\section{System alternatywnego dochodzenia roszczeń w Polsce}

Polski system oparty jest na pojęciu „zdarzenia medycznego”. Definicja legalna tego pojęcia znajduje się w art. 67 a ustawy z dnia 6 listopada 2008 roku o prawach pacjenta i Rzeczniku Praw Pacjenta (dalej: u.p.p.). Składa się ona z dwóch elementów: skutku i zdarzenia będącego jego przyczyna. Skutki zawarte w zakresie definicji to: zakażenie pacjenta biologicznym czynnikiem chorobotwórczym, uszkodzenie ciała lub rozstrój zdrowia pacjenta oraz śmierć pacjenta. Do przyczyn należą: diagnoza, która spowodowała niewłaściwe leczenie albo opóźniła właściwe leczenie, przyczyniając się do rozwoju choroby, leczenie, w tym wykonanie zabiegu operacyjnego, zastosowanie produktu leczniczego lub wyrobu medycznego. Do przesłanek zdarzenia medycznego zalicza się także fakt niezgodności tych działań z aktualną wiedzą medyczną. Co więcej, zgodnie z u.p.p. prawnie istotne są tylko te zdarzenia medyczne, które nastapiły w wyniku udzielania świadczeń zdrowotnych w szpitalu w rozumieniu przepisów o działalności leczniczej. W razie zaistnienia zdarzenia medycznego szpital (badź ubezpieczyciel, jeśli zawarto umowę ubezpieczenia) jest zobowiązany do wypłaty świadczenia. Z jednej strony, definicja zdarzenia medycznego jest więc węższa od definicji błędu medycznego, poprzez ograniczenie podmiotowe do szpitali oraz ograniczenie skutków i zdarzeń będących jego przyczyną. Z drugiej strony, fakt, że to nie lekarz, a jednostka, w której działa, ponosi odpowiedzialność, ma kluczowe znaczenie dla skutecznego dochodzenia roszczeń - jak słusznie wskazuje Iwona Dobkowska-Puławska, definicja ta „nie odnosi się do błędu ludzkiego, koncentrując się na organizacji procesu leczenia” 3 .

Sprawy dotyczące zdarzeń medycznych rozpatrują wojewódzkie komisje do spraw orzekania o zdarzeniach medycznych (dalej: wojewódzkie komisje). Postępowanie rozpoczyna się na wniosek o ustalenie zdarzenia medycznego, wnoszony przez poszkodowanego wraz z uiszczeniem niewysokiej opłaty. We wniosku wskazywana jest także propozycja wysokości odszkodowania i zadośćuczynienia za przedmiotowe zdarzenie. Wojewódzka komisja w toku postępowania wydaje orzeczenie o zdarzeniu medycznym albo jego braku - celem jej działań jest jedynie ustalenie, czy doszło do zdarzenia spełniającego przesłanki określone w ustawie. W razie ustalenia,

2. M. Nesterowicz, M. Wałachowska, Odpowiedzialność za szkody wyrzqdzone przy leczeniu w zwiqzku z nowym pozasqdowym systemem kompensacji szkód medycznych, [w:] Kompensacja szkód wynikłych ze zdarzeń medycznych - problematyka cywilnoprawna i ubezpieczeniowa, [red.] E. Kowalewski, TNOiK, Toruń 2011, s. 1 ?.

3. I. Dobkowska-Puławska, R. Kazimierowicz, B. Reczuch, Pacjent i jego prawa w kontekście odpowiedzialności za błędy medyczne, [w:] Międzynarodowe standardy ochrony praw człowieka a doświadczenia Polski, [red.] J. Jaskiernia, K. Spyszak, Wydawnictwo Adam Marszałek, Toruń 2016, s. 258. 
Praktyczne problemy działania polskiego systemu alternatywnego dochodzenia roszczeń...

że do zdarzenia medycznego doszło, ubezpieczyciel (a w jego braku - szpital) jest zobowiązany do przedstawienia wnioskodawcy propozycji odszkodowania i zadośćuczynienia, w wysokości nieprzekraczającej ustawowych limitów. W wypadku, gdy ubezpieczyciel (szpital) nie złoży propozycji w terminie 30 dni, będzie zobowiązany do wypłaty świadczeń w wysokości wskazanej we wniosku. Postępowanie kończy się przyjęciem badź odrzuceniem propozycji. Ustawa nie przewiduje procedury negocjacyjnej co do samej wysokości roszczenia.

Jednym z podstawowych założeń systemów alternatywnych na świecie jest maksymalne uproszczenie dochodzenia odpowiedzialności za błędy (zdarzenia) medyczne z jednoczesnym wprowadzeniem systemu obowiązkowych ubezpieczeń. Na płaszczyźnie założeń ustawodawczych polski system spełnia to założenie. Niestety, analiza efektów jego wdrożenia wskazuje, że wiele elementów nie działa w praktyce. Początkowo jedynie jeden ubezpieczyciel wprowadził do swojej oferty ubezpieczenie dla szpitali, a ze względu na wysokie składki wiele podmiotów medycznych nie przystapiło do ubezpieczenia ${ }^{4}$. Wymóg zawarcia umowy ubezpieczenia najpierw więc czasowo zawieszono, a ostatecznie zniesiono w 2016 roku.

Innym istotnym elementem systemów na świecie jest ich alternatywność względem dochodzenia odszkodowania przed sądem. Choć pobieżna lektura u.p.p. wskazuje, że polski system spełnia ten wymóg, ponieważ postępowanie przed wojewódzką komisją nie zamyka drogi sądowej, to w praktyce jego alternatywność względem sądów może okazać się jedynie pozorna. Mowa tu przede wszystkim o art. 67k ust. 6 u.p.p., zgodnie z którym w przypadku przyjęcia propozycji świadczenia podmiot składający wniosek „składa oświadczenie o zrzeczeniu się wszelkich roszczeń o odszkodowanie i zadośćuczynienie pieniężne za doznaną krzywdę, mogạcych wynikać ze zdarzeń uznanych przez wojewódzką komisję za zdarzenie medyczne w zakresie szkód, które ujawniły się do dnia złożenia wniosku". Korzystając z alternatywnego systemu, poszkodowany może zatem uzyskać odszkodowanie łatwiej, będzie ono jednak mniejsze ze względu na ograniczenia wysokości świadczenia przewidziane w u.p.p. oraz w rozporządzeniu Ministra Zdrowia z dnia 27 czerwca 2013 roku w sprawie szczegółowego zakresu oraz warunków ustalania wysokości świadczenia w przypadku zdarzenia medycznego (Dz. U. 2013, poz. 750, dalej: rozporządzenie kwotujące). Choć rozwiązanie takie wpisuje się w założenia systemu no fault compensation, to niskie kwoty faktycznie proponowane przez szpital moga znacząco obniżać rzeczywistą przydatność systemu, ponieważ poszkodowani moga decydować się na podjęcie próby uzyskania wyższego odszkodowania przed sądem.

\section{Założenia przy wprowadzeniu polskiego systemu}

Wprowadzenie alternatywnego systemu dochodzenia roszczeń wiązało się z szeregiem oczekiwań. Podstawowym założeniem zawartym w uzasadnieniu do projektu nowelizacji ustawy było wprowadzenie rozwiązania, które pozwoli uzyskać odszkodowanie lub zadośćuczynienie w ciagu 3 miesięcy. Po drugie, obniżone miały zostać koszty uzyskania świadczenia - zamiast stosunkowej opłaty w wysokości 5\% wartości przedmiotu sporu (zgodnie z ówczesnym brzmieniem ustawy o kosztach sądowych w postępowaniu cywilnym) wprowadzono niską opłatę podstawową, co miało na celu ułatwienie pacjentom dostępu do odszkodowania. Prognozowano także, że może nastapić

4. M. Serwach, Ubezpieczenia z tytułu zdarzeń medycznych w teorii i praktyce, „Prawo Asekuracyjne” 2012, nr 4, s. ?. 
niewielki wzrost dochodzonych odszkodowań. Wprowadzone rozwiązanie miało mieć charakter „ugodowo-mediacyjny5”. Założeniem systemu było także odciążenie wymiaru sprawiedliwości.

Ubezpieczyciel (bąź szpital) składający propozycję świadczenia powinien opierać się na zasadach określonych w rozporządzeniu kwotującym, w którym wprowadzono szereg dodatkowych ograniczeń kwotowych dla szkód wyrządzonych przez różnego rodzaju zdarzenia medyczne, a także zasady przeliczania różnych typów uciążliwości leczenia i innych krzywd na procentowy stopień uciążliwości leczenia lub innej krzywdy. W praktyce jednak podnosi się, że ubezpieczyciele nie zawsze przestrzegają zasad określonych w rozporządzeniu kwotującym ${ }^{6}$.

Kolejną wada systemu jest zasada określona w art. 67 d ust. 5 u.p.p., zgodnie z która „wniosek niekompletny lub nienależycie opłacony jest zwracany bez rozpatrzenia podmiotowi składającemu wniosek". W praktyce właśnie brak wniesienia opłaty lub błędy w wypełnieniu wniosku stanowia częsta podstawę zwrotu wniosków? Istotnym utrudnieniem jest również termin na wniesienie wniosku, który zgodnie z art. 67 c ust. 2 u.p.p. wynosi 1 rok od dnia, w którym podmiot składający wniosek dowiedział się o zdarzeniu medycznym, ale nie dłużej niż 3 lata od dnia, w którym zdarzenie nastapiło. Termin ten jest wyraźnie krótszy od terminu przedawnienia roszczenia określonego w Kodeksie cywilnym. W uzasadnieniu projektu ustawy wskazywano, że jest to wystarczający termin dla pacjentów, jednak wydaje się, że w praktyce uniemożliwi to skorzystanie z postępowania przed wojewódzką komisją w przypadku części roszczeń, które sạjeszcze wymagalne.

Krytycznie odniesiono się także do terminu 3 miesięcy przewidzianego na rozpoznanie sprawy przez wojewódzką komisję. Termin ten ma charakter jedynie terminu instrukcyjnego ${ }^{8}$. Podejrzewano, że o ile w początkowym okresie jego dotrzymanie będzie możliwe, to wraz ze wzrostem liczby spraw wojewódzkie komisje nie będą w stanie przeprowadzić postępowania odpowiednio szybko. Jako szczególnie utrudniający dochowanie terminu uznawano określony w art. 67 d ust. 6 u.p.p. obowiązek przekazania wniosku szpitalowi i ubezpieczycielowi, którzy następnie mają 30 dni od dnia otrzymania wniosku na przedstawienie stanowiska w sprawie. Jak słusznie zauważa Małgorzata Serwach, w ten sposób upływa ponad jedna trzecia czasu na rozpatrzenie wniosku przez wojewódzką komisję .

Kolejnym mankamentem wprowadzonego modelu jest fakt, że - w przeciwieństwie do procedury cywilnej - brak w nim przepisów o współuczestnictwie. Ma to istotne znaczenie w kontekście współuczestnictwa biernego, ponieważ charakter zdarzeń medycznych sprawia, że czasami możliwe jest jedynie ustalenie, że do zakażenia doszło w jednym z dwóch szpitali, ale bez możliwości określenia, w którym ${ }^{10}$. Złożenie wniosku przeciwko dwóm szpitalom nie będzie w aktualnie wprowadzonym systemie możliwe. Początkowo jako istotne ograniczenie podmiotowe systemu

5. Uzasadnienie do rządowego projektu ustawy o zmianie ustawy o prawach pacjenta i Rzeczniku Praw Pacjenta oraz niektórych innych ustaw, VI Kadencja, druk sejm. nr 3488, s. ?.

6. M. Śliwka, Wybrane czynniki determinujqce działalność wojewódzkich komisji orzekajqcych o zdarzeniach medycznych, „Prawo i Medycyna” 2012, nr 3/4, s. 13.

7. Ibidem, s. ?-8.

8. J. Glanc, Orzekanie o zdarzeniach medycznych, [w:] Prawne aspekty reformy systemu ochrony zdrowia w Polsce, [red.] K. F. Bolt, D. Sieniawska-Michalska, B. Węgrzynowski, Wydawnictwo Instytutu Studiów Europejskich, Gdynia 2013, s. 200.

9. M. Serwach, op. cit., s. 14. Należy zaznaczyć, że ostatecznie w u.p.p. przewidziano termin 4 miesięcy na rozpoznanie sprawy. Pomimo tej zmiany, w ocenie autora, przytoczone wątpliwości zachowały aktualność.

10. I. Zduński, Zdarzenie medyczne - bład medyczny w „nowej szacie”, [w:] Oblicza Temidy. Aspekty prawne ochrony zdrowia, [red.] I. Zgoliński, Wydawnictwo Kujawsko-Pomorskiej Szkoły Wyższej, Bydgoszcz 2013, s. 48. 
Praktyczne problemy działania polskiego systemu alternatywnego dochodzenia roszczeń...

wskazywano to, że dotyczy zdarzeń, do których doszło tylko w niektórych podmiotach ${ }^{11}$. Zasada ta jest aktualna także dziś, zgodnie z art. 67 a ust. 2 u.p.p. przepisy o postępowaniu przed wojewódzką komisją stosuje się jedynie do zdarzeń medycznych będących następstwem udzielania świadczeń zdrowotnych w szpitalu w rozumieniu przepisów ustawy z dnia 15 kwietnia 2011 roku o działalności leczniczej (Dz. U. 2018, poz. 2190), jednak szeroki zakres tej definicji sprawia, że ograniczenie to nie ma poważnego wpływu na działalność systemu.

\section{Metodologia badań}

W celu zgromadzenia danych na temat działania systemu zwrócono się do Rzecznika Praw Pacjenta o udostępnienie danych dotyczących: liczby wniesionych wniosków o ustalenie zdarzenia medycznego, liczby wniosków uwzględnionych, wysokości kwoty świadczenia proponowanej przez ubezpieczyciela (badź szpital) w przypadku wydania orzeczenia o zdarzeniu medycznym, czasu od wpłynięcia wniosku do zakończenia postępowania, liczby przypadków, w których składający wniosek odrzucił propozycję ubezpieczyciela (bądź szpitala), liczby biegłych ${ }^{12}$ powołanych w sprawie oraz źródła wypłaty świadczenia (czy zostało wypłacone na podstawie umowy ubezpieczenia zawartej przez szpital, czy ze środków własnych szpitala]. Wnioskiem objęte zostały dane z całego okresu działania wojewódzkich komisji. Jednakże, ponieważ wojewódzkie komisje nie maja obowiązku prowadzenia ewidencji spraw, nie wszystkie dane objęte wymienionym zakresem udało się uzyskać. Stosowne zastrzeżenia dotyczące dostępności danych zostaną zaznaczone w odpowiednich fragmentach omówienia wyników. Poza danymi uzyskanymi od Rzecznika Praw Pacjenta wykorzystano dane ze sprawozdań Rzecznika Praw Pacjenta za lata 2012-2018 oraz wyniki kontroli przeprowadzonej przez Naczelną Izbę Kontroli dotyczące lat 2014-2018. Analizą objęte zostały także dostępne dane statystyczne na temat działalności sądów powszechnych, aby sprawdzić, czy działanie alternatywnego systemu dochodzenia roszczeń przełożyło się na zmniejszenie liczby wpływających spraw o odszkodowania za szkody wyrządzone przez służbę zdrowia.

Interesujące było także, czy pacjenci decydowali się na przerwanie procedury przed wojewódzką komisją na rzecz dochodzenia odszkodowania przed sądem. Niestety, informacja taka nie jest przedmiotem badań statystycznych prowadzonych przez sądy, a zatem nie można było w tym zakresie posiłkować się danymi dostępnymi na stronach Ministerstwa Sprawiedliwości. Wojewódzkie komisje również nie mają obowiązku prowadzenia ewidencji takich spraw, w związku z czym także one nie były w stanie udzielić potrzebnych informacji. Źródłem danych w tym zakresie jest jednak Informacja o wynikach kontroli pozasądowego dochodzenia roszczeń przez pacjentów przeprowadzonej przez Naczelną Izbę Kontroli w roku $2018^{13}$. Ewidencja w powyższych

11. E. Kowalewski, M. Śliwka, M. Wałachowska, Kompensacja szkód wynikłych z „błędów medycznych”. Ocena projektowanych rozwiqzań prawnych, „Prawo i Medycyna” 2010, nr 4, s. 25.

12. Należy podkreślić, że termin „biegły” jest w przypadku tego postępowania używany jedynie zwyczajowo. Ustawa nie posługuje się tym pojęciem, a jedynie pojęciami lekarza w danej dziedzinie medycyny z listy, o której mowa w art. 32 ust. 2 [lista lekarzy, którzy mogą być członkami Komisji Lekarskiej - przyp. M. K.], albo konsultanta wojewódzkiego $w$ danej dziedzinie medycyny, farmacji lub innej dziedzinie mającej zastosowanie w ochronie zdrowia (por. art. 67i ust. ? u.p.p.).

13. Informacja o wynikach kontroli: Pozasądowe dochodzenie roszczeń przez pacjentów, KZD.430.005.2018, nr ewid. 163/2018/P/18/057/KZD. 
źródłach prowadzona była w oparciu o różne standardy, co często utrudnia proste zestawienia danych z różnych obszarów i ogranicza możliwości wnioskowania.

\section{Omówienie wyników}

\subsection{Liczba wniesionych wniosków}

Podstawowym pytaniem, na które odpowiedź jest konieczna dla oceny działania systemu, jest to, czy pacjenci rzeczywiście są zainteresowani korzystaniem z niego. W ciagu 8 lat funkcjonowania systemu łącznie złożono 7229 wniosków. Wykres 1 obrazuje zmiany w liczbie wniosków wnoszonych w kolejnych latach.

\section{Wykres 1. Liczba wniesionych wniosków}

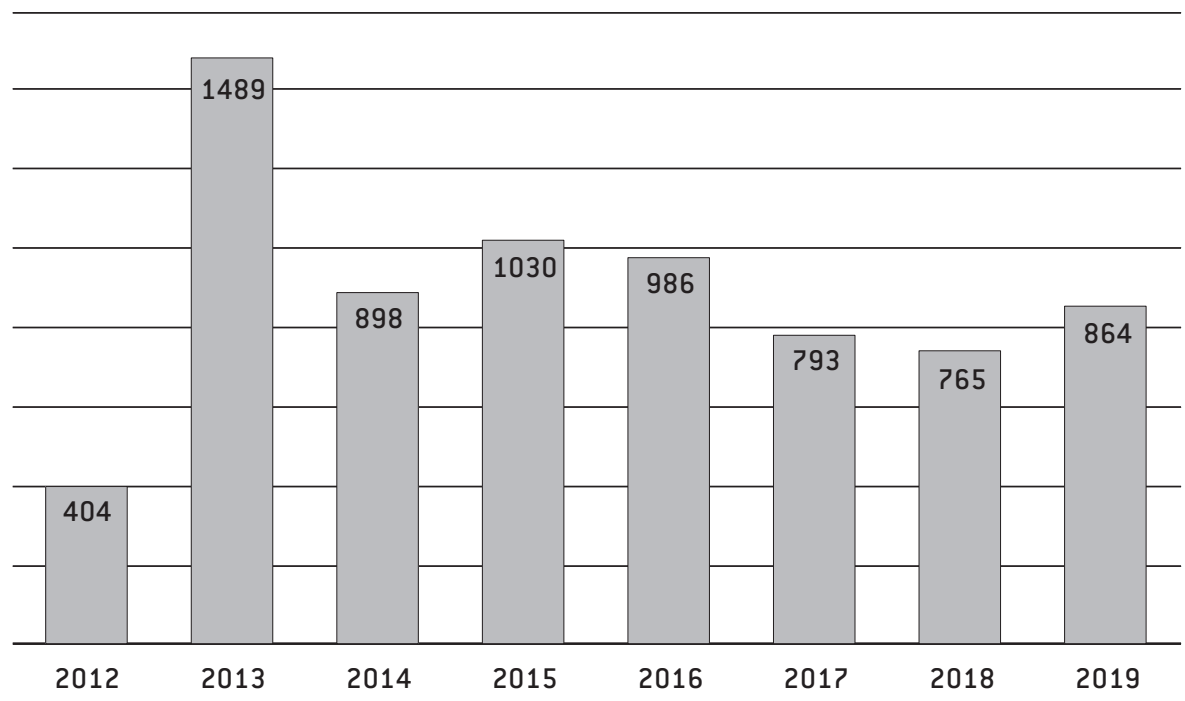

Źródło: opracowanie własne, na podstawie danych udostępnionych przez Rzecznika Praw Pacjenta.

Jak widać, po początkowym zainteresowaniu nowym systemem rozpoczęła się trwająca do dziś tendencja spadkowa w zakresie liczby wpływających spraw. Przemawia to za przyjęciem tezy, że aktualnie system nie działa w sposób zadowalający dla pacjentów ${ }^{14}$.

Sama liczba wniesionych wniosków nie obrazuje jeszcze „popularności” systemu. W celu uzyskania dokładniejszego obrazu dane dotyczące wniosków w poszczególnych województwach przeanalizowano względem liczby mieszkańców. Widać wyraźnie, że przez cały okres działania systemu nie pojawiło się więcej niż średnio 4 sprawy na 100 tys. mieszkańców danego województwa. Szczegółowe wyniki przedstawia poniższa Tabela 1.

14. Taki wniosek wynika także ze sprawozdania Rzecznika Praw Pacjenta dotyczącego przestrzegania praw pacjenta na terytorium Rzeczypospolitej Polskiej za rok 2018, s. 69. 
Praktyczne problemy działania polskiego systemu alternatywnego dochodzenia roszczeń...

Tabela 1. Liczba wniesionych wniosków w przeliczeniu na 100 tys. mieszkańców w latach 2012-2019

\begin{tabular}{|l|c|c|c|c|c|c|c|c|}
\hline \multicolumn{1}{|c|}{ Województwo } & $\mathbf{2 0 1 2}$ & $\mathbf{2 0 1 3}$ & $\mathbf{2 0 1 4}$ & $\mathbf{2 0 1 5}$ & $\mathbf{2 0 1 6}$ & $\mathbf{2 0 1 7}$ & $\mathbf{2 0 1 8}$ & $\mathbf{2 0 1 9}$ \\
\hline Dolnoślaskie & 1,03 & 4,40 & 2,44 & 3,41 & 3,17 & 2,27 & 2,03 & 2,38 \\
\hline Kujawsko-pomorskie & 1,67 & 5,40 & 2,25 & 3,07 & 2,83 & 2,74 & 2,84 & 3,23 \\
\hline Lubelskie & 0,51 & 2,08 & 1,81 & 1,87 & 2,11 & 1,88 & 1,27 & 2,23 \\
\hline Lubuskie & 0,78 & 3,33 & 2,35 & 3,63 & 2,26 & 3,74 & 1,58 & 1,58 \\
\hline Łódzkie & 1,07 & 2,82 & 2,15 & 2,44 & 2,13 & 1,73 & 2,02 & 2,28 \\
\hline Małopolskie & 1,22 & 4,05 & 2,20 & 2,43 & 2,22 & 2,19 & 2,77 & 2,00 \\
\hline Mazowieckie & 1,00 & 4,28 & 2,39 & 3,24 & 2,78 & 2,25 & 2,02 & 2,86 \\
\hline Opolskie & 1,78 & 5,96 & 2,39 & 2,60 & 2,01 & 1,21 & 2,43 & 3,25 \\
\hline Podkarpackie & 0,85 & 2,63 & 2,07 & 1,46 & 1,97 & 2,11 & 1,88 & 2,16 \\
\hline Podlaskie & 0,67 & 4,26 & 3,02 & 2,44 & 3,37 & 2,11 & 3,80 & 2,80 \\
\hline Pomorskie & 1,44 & 4,01 & 3,22 & 3,43 & 3,72 & 1,81 & 2,19 & 2,10 \\
\hline Śląskie & 0,95 & 3,50 & 1,89 & 1,77 & 2,54 & 1,56 & 0,90 & 1,30 \\
\hline Świętokrzyskie & 0,86 & 2,91 & 1,58 & 2,06 & 1,99 & 1,20 & 0,56 & 1,29 \\
\hline Warmińsko-Mazurskie & 0,76 & 4,14 & 1,87 & 3,05 & 2,30 & 1,67 & 0,91 & 0,77 \\
\hline Wielkopolskie & 0,95 & 3,87 & 3,06 & 2,79 & 2,56 & 2,09 & 2,66 & 2,69 \\
\hline Zachodniopomorskie & 1,34 & 4,88 & 2,56 & 3,56 & 2,28 & 2,75 & 2,17 & 2,71 \\
\hline Cała Polska & 1,05 & 3,87 & 2,33 & 2,68 & 2,57 & 2,06 & 1,99 & 2,25 \\
\hline
\end{tabular}

Źródło: opracowanie własne, na podstawie danych udostępnionych przez Rzecznika Praw Pacjenta oraz danych GUS.

Ważnym aspektem dotyczącym każdego systemu jest sprawność jego funkcjonowania. Miernikiem obrazującym ten aspekt jest wzrastająca bądź malejąca liczba przyjętych i nierozwiązanych spraw. Należy tutaj pamiętać, że - ze względu na stopień skomplikowania - sprawy moga być rozpatrywane przez rok i dłużej. Dlatego zdecydowano się na pokazanie udziału skumulowanej liczby zakończonych spraw w odniesieniu do skumulowanej liczby wszystkich wniosków. Wykres 2 pokazuje trend, który wyraźnie wskazuje na rosnący z roku na rok odsetek spraw zakończonych, co można uznać za wskazujące na rosnącą sprawność wprowadzonego systemu.

Wykres 2. Udział spraw zakończonych w całości rozpatrywanych spraw

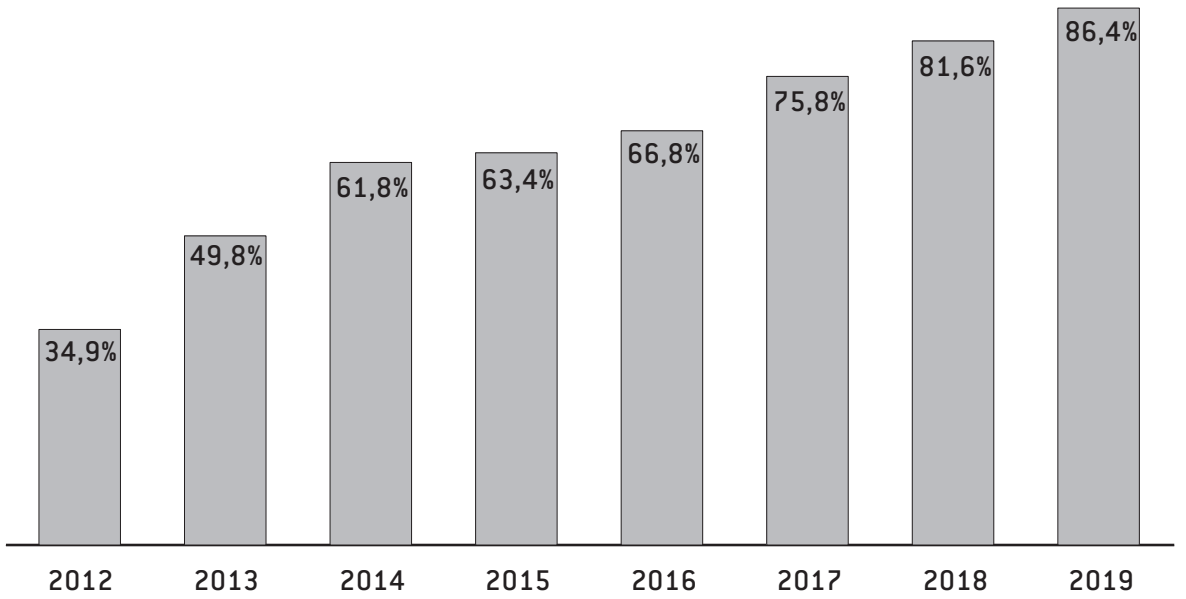

Źródło: opracowanie własne, na podstawie danych udostępnionych przez Rzecznika Praw Pacjenta. 


\subsection{Sposób rozpatrzenia wniosków złożonych do komisji}

Kolejnym interesującym zagadnieniem jest to, w jaki sposób komisje rozstrzygają przedłożone wnioski. Po przeanalizowaniu przedstawionych danych okazało się, że przed odpowiedzią na to pytanie warto zwrócić uwagę, ile ze złożonych wniosków w ogóle nie zostało rozpatrzonych i zwróconych bez rozpoznania (wnioski niekompletne lub nienależycie opłacone). Jak widać na poniższym wykresie, udział spraw pozostawionych bez rozpoznania jest stosunkowo wysoki. Nawet biorąc pod uwagę, że w pierwszym roku działania systemu stosunkowo wielu pacjentów mogło nie znać nowej procedury, trzeba zauważyć, że także w późniejszych latach nie spadł on poniżej $15 \%{ }^{15}$. Niestety, ze względu na brak dostępu do danych o oddalaniu pism inicjujacych postępowanie z analogicznych przyczyn w innych procedurach, nie jest możliwe określenie, czy jest to wartość typowa, czy odbiegająca od normy.

Wykres 3. Udział wniosków zwróconych bez rozpoznania w całości wniesionych wniosków

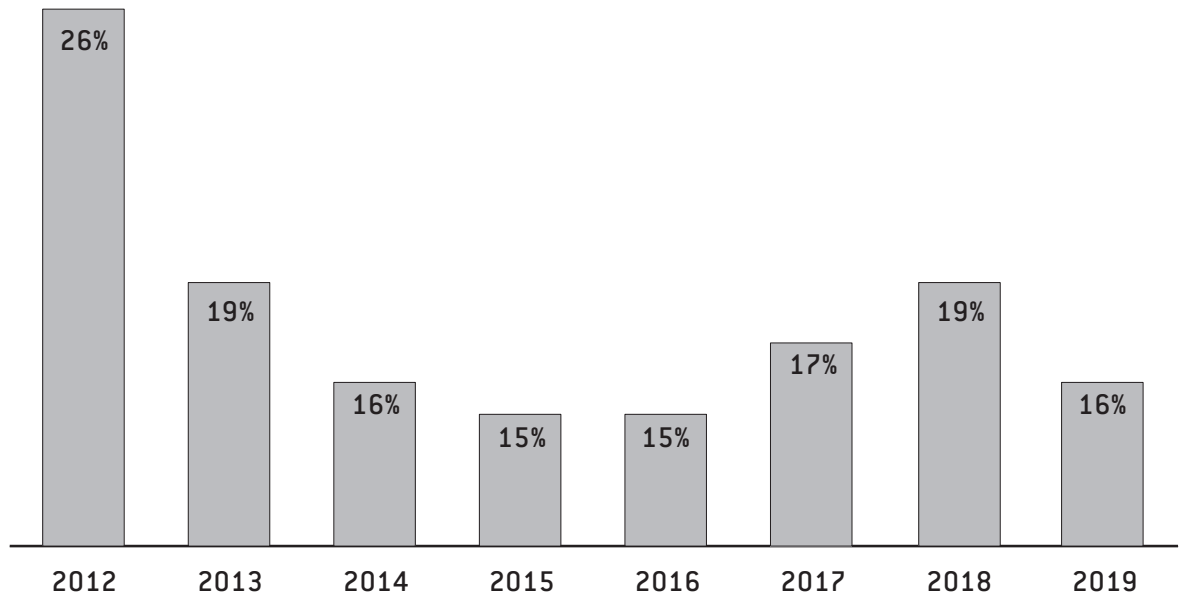

Źródło: opracowanie własne, na podstawie danych udostępnionych przez Rzecznika Praw Pacjenta.

Postępowanie co do zasady kończy się rozstrzygnięciem, w którym stwierdza się zdarzenie medyczne albo jego brak. Przez cały okres funkcjonowania systemu w 1561 ze wszystkich rozpatrzonych spraw stwierdzono zdarzenie medyczne, w 2984 - brak zdarzenia, a 371 spraw zostało zakończonych z przyczyn formalnych (wykres 4).

15. Przy ocenie wyników należy mieć na względzie, że może zachodzić faktyczne dublowanie danych o liczbie wpływających spraw, ponieważ zwrócony wniosek, jeśli zostanie ponownie wniesiony, może być zarejestrowany jako nowy wniosek pod nową sygnaturą. 
Wykres 4. Rozkład rozstrzygniętych wniosków w latach 2012-2019

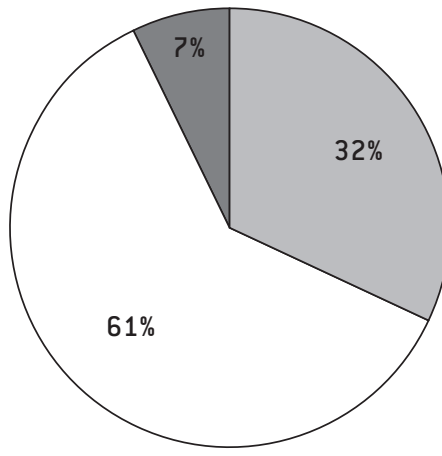

Zdarzenia medyczne

Brak zdarzenia medycznego

Nierozstrzygnięte z przyczyn formalnych

Źródło: opracowanie własne, na podstawie danych udostępnionych przez Rzecznika Praw Pacjenta.

Zdarzenia medyczne stwierdzono w prawie jednej trzeciej wszystkich przypadków. W niemalże dwóch trzecich - brak zdarzenia. Zakładając, że wojewódzkie komisje dokonywały poprawnych ustaleń, można uznać, że wniesienie przez pacjentów spraw do sądu skutkowałoby brakiem uzyskania odszkodowania, przy jednoczesnym poniesieniu znacznie wyższych kosztów postępowania. Można więc uznać, że system osiaggnałł w pewnym sensie sukces, oszczędzając poszkodowanym dodatkowych kosztów w sytuacjach, gdzie brak było przesłanek do przypisania odpowiedzialności szpitalowi. Warto także zauważyć, że wniosek o ponowne rozpoznanie sprawy (przez pacjenta badź szpital) wniesiono w 2193 przypadkach - a zatem w 48\% wszystkich rozpatrzonych merytorycznie spraw, niezależnie od tego, jaki był wynik pracy komisji.

\subsection{Wysokość proponowanej kwoty świadczenia oraz liczba przypadków, w których propozycję odrzucono}

Wojewódzkie komisje nie mają obowiązku prowadzenia ewidencji złożonych propozycji i kwot zaakceptowanych i otrzymanych przez wnioskodawców. W związku z tym przedstawione poniżej informacje są oparte na danych niepełnych. Wynika z nich jednak, że proponowane kwoty wahaja się od 1 zł do maksymalnej ustawowej - 300 tys. złotych. Najbardziej szczegółowe dane dotyczące wysokości proponowanych kwot oraz tego, czy propozycja ta została przyjęta, udało się ustalić za rok 2016. Przedstawione poniżej informacje zawierają dane ze wszystkich województw, poza: lubelskim, łódzkim, podkarpackim i zachodniopomorskim. Na potrzeby opracowania przyjęto, że brak zaproponowania przez szpital (ubezpieczyciela) żadnej kwoty (co w konsekwencji prowadzi do przyznania kwoty żądanej] jest równoznaczny z akceptacja propozycji, a brak odpowiedzi na propozycję jest równoznaczny z jej odrzuceniem. Najniższa zaproponowana kwota w 2016 roku wyniosła 1 zł, a najwyższa - 100 tys. złotych. Po przeanalizowaniu danych można wyróżnić trzy przedziały ich wysokości, w których zmienia się procentowy udział propozycji przyjętych. Wyodrębniono następujące przedziały według wysokości propozycji: od 1 zł do 1000 zł włącznie, od 1001 zł do 10000 zł włącznie, oraz powyżej 10000 zł. Udział przyjętych propozycji prezentuja poniższe wykresy. 
Wykres 5.1. Przyjęte i odrzucone propozycje w wysokości od 1 do 1000 zł

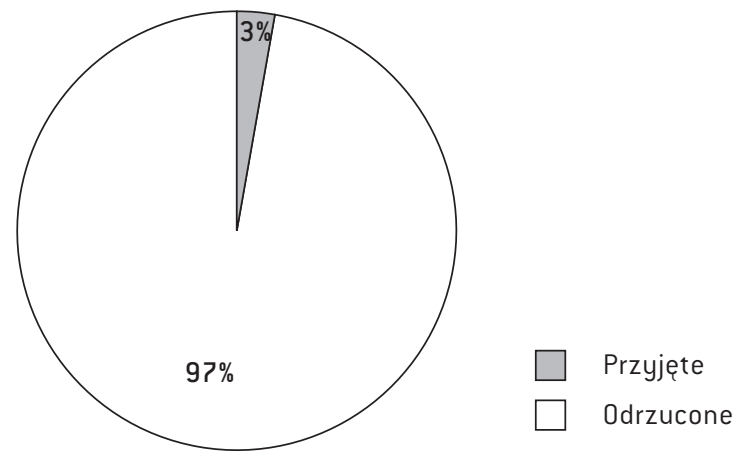

Wykres 5.2. Przyjęte i odrzucone propozycje w wysokości od 1001 do 10000 zł

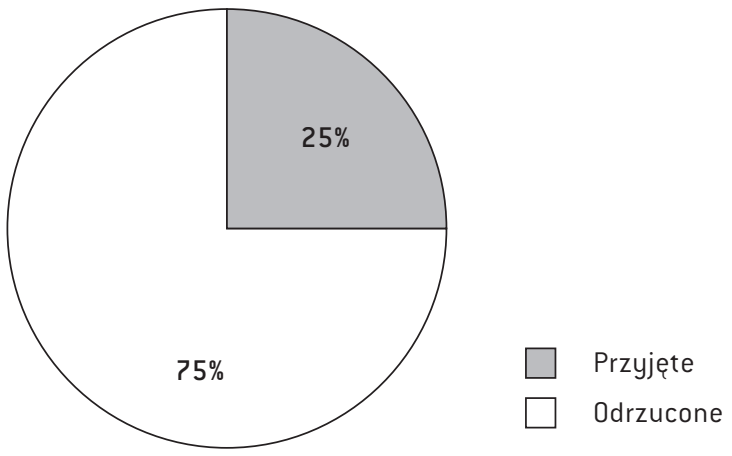

Wykres 5.3. Przyjęte i odrzucone propozycje w wysokości powyżej 10000 zł

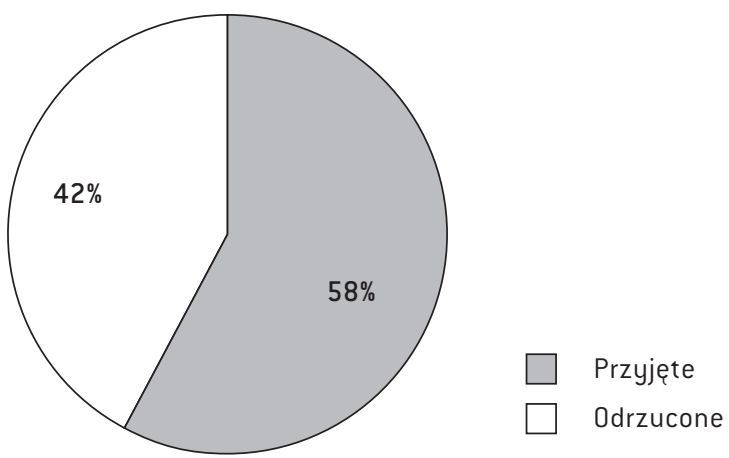

Źródło: opracowanie własne, na podstawie danych udostępnionych przez Rzecznika Praw Pacjenta.

Widać wyraźnie, że przy niższych kwotach dominuja propozycje odrzucone. Dopiero przy kwotach powyżej 10000 zł większość pacjentów zdecydowała się na przyjęcie propozycji. Prawdopodobnie przyczyną tego jest duża różnica pomiędzy kwotami żądanymi we wniosku a kwotami proponowanymi przez podmiot zobowiązany, przy jednoczesnej konieczności zrzeczenia się z dalszych roszczeń w przypadku przyjęcia propozycji. Negatywnie należy ocenić regularne proponowanie 
Praktyczne problemy działania polskiego systemu alternatywnego dochodzenia roszczeń...

kwot niższych niż przewidziane rozporządzeniem kwotującym, czasami nawet tak niskimi jak 100 zł, czy nawet 1 zł.

\subsection{Czas od wpłynięcia wniosku do zakończenia postępowania}

Brak dokładnych danych dotyczących czasu prowadzenia postępowania za lata 2012-2013. Ze sprawozdań Rzecznika Praw Pacjenta dotyczacych przestrzegania praw pacjenta na terytorium Rzeczypospolitej Polskiej w tym okresie wynika jednak, że już w pierwszych latach działania systemu wojewódzkim komisjom nie udawało się zakończyć wszystkich spraw w ustawowym terminie 4 miesięcy. Dokładne informacje dostępne sa jedynie za okres 2014-2017 w związku z kontrola przeprowadzona przez NIK. W ramach kontroli przeanalizowano dokumentację dotycząca 288 spraw zakończonych w tym okresie. Spośród nich tylko 123 sprawy [47,3\%] zostały zakończone w ustawowym terminie czterech miesięcy. W terminie od 4 do 6 miesięcy zakończonych zostało 64 spraw $(24,6 \%)$, a 73 sprawy (28,1\%) w terminie powyżej 6 miesięcy. Najdłuższy czas do wydania orzeczenia różnił się w zależności od komisji i wynosił od 6,4 miesiąca do aż 22,3 miesiąca. Na wydłużanie czasu trwania postępowania niewątpliwy wpływ ma także wspomniany wyżej obowiązek przedstawienia wniosku podmiotowi zobowiązanemu celem zajęcia przez niego stanowiska. Kontrola przeprowadzona przez NIK wykazała, że okres ten wynosił zwykle od 9 do 30 dni, choć zdarzył się także przypadek otrzymania stanowiska dopiero po 53 dniach. Jednakże większy wpływ na opóźnienia niż samo oczekiwanie na odpowiedź szpitala miały działania szpitala - kontrola wskazała na długi okres od uzyskania stanowiska szpitala do pierwszego posiedzenia (przeciętnie od 38 do 108 dni; maksymalny stwierdzony okres wyniósł 379 dni).

\subsection{Liczba biegłych powołanych w sprawie}

Informacje w tym zakresie znajdują się przede wszystkim w sprawozdaniu z kontroli przeprowadzonej przez NIK za lata 2014-2018 oraz w danych uzyskanych od RPP za lata 2017-2019. Z samych przepisów u.p.p. wynika, że zasięgnięcie opinii biegłego jest konieczne wtedy, gdy „stwierdzenie okoliczności mających istotne znaczenie dla wydania orzeczenia wymaga wiadomości specjalnych". W wyniku kontroli ustalono, że wojewódzkie komisje często korzystają z opinii biegłych. Wojewódzkie komisje poddane kontroli w przedmiotowym okresie skorzystały z opinii biegłych przy rozstrzygnięciu 116 spośród 336 spraw [34,6\%). W tych 116 sprawach złożono wnioski o aż 163 opinie, przy czym ostatecznie otrzymano ich 138. Należy przy tym zaznaczyć, że komisje w różnych województwach opierały się na opiniach biegłych w bardzo różnym stopniu. Znalazło to także odzwierciedlenie w czasie trwania postępowania, w związku z tym, że średni czas sporządzenia jednej opinii przez biegłego wyniósł 59 dni, a najdłuższy - aż 639 dni. W konsekwencji, sprawy, w których nie zwrócono się o opinię biegłych, były rozstrzygane w I instancji średnio w ciaggu 3,9 miesiąca (a więc w terminie przewidzianym ustawą). Z kolei w sprawach, w których przeprowadzano opinie biegłych, średni czas rozpatrzenia sprawy wyniósł niemalże dwukrotnie dłużej - aż 7,7 miesiąca. W II instancji wartości te wyniosły odpowiednio 58,1 dnia przy braku opinii biegłych i 172,1 dnia w przypadkach, gdy zwrócono się o tę opinię. Dane za rok 2019 nie pozwalają na określenie procentowego udziału korzystania z opinii biegłych przy rozstrzyganiu spraw. Ujawniono jedynie, że komisje wydały w tym okresie 493 postanowienia o powołaniu biegłego. 


\subsection{Wpływ alternatywnego systemu dochodzenia roszczeń na działanie sądów powszechnych}

Rok 2011 był ostatnim przed wprowadzeniem alternatywnego trybu dochodzenia roszczeń za zdarzenia medyczne, dlatego też porównanie danych pomiędzy tym rokiem a latami późniejszymi jest interesujące dla ustalenia wpływu, jaki miało wprowadzenie alternatywnego systemu dochodzenia roszczeń na liczbę spraw wnoszonych przed sądy powszechne. Zgodnie z danymi Ministerstwa Sprawiedliwości o postępowaniach dotyczących odszkodowania i zadośćuczynienia za szkody wyrządzone przez służbę zdrowia za lata 2011-2017 liczba nowych spraw w I instancji rysowała się następująco.

Wykres 6. Liczba spraw odszkodowawczych w I instancji

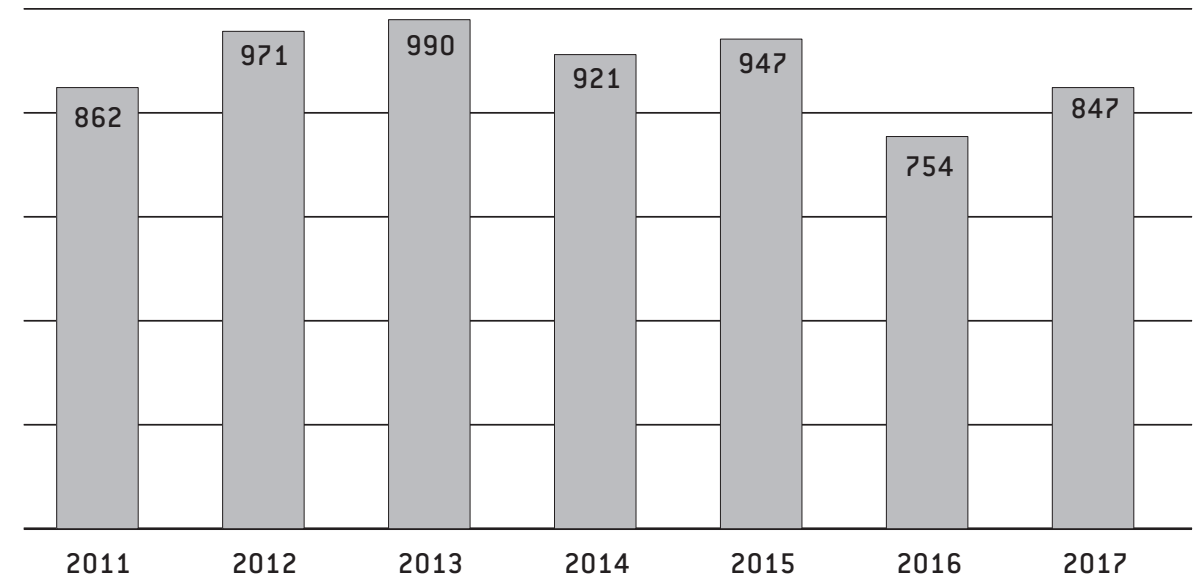

Źródło: opracowanie własne, na podstawie danych udostępnionych przez Ministerstwo Sprawiedliwości.

Z wykresu wynika, że wprowadzenie alternatywnego systemu dochodzenia roszczeń nie odciążyło sądownictwa. Jednakże interesującą zależność widać, gdy rozdzielimy sprawy odszkodowawcze w I instancji na rozpatrywane przez sądy rejonowe i rozpatrywane przez saddy okręgowe. 
Wykres ?. Liczba spraw odszkodowawczych w I instancji w sądach rejonowych oraz okręgowych

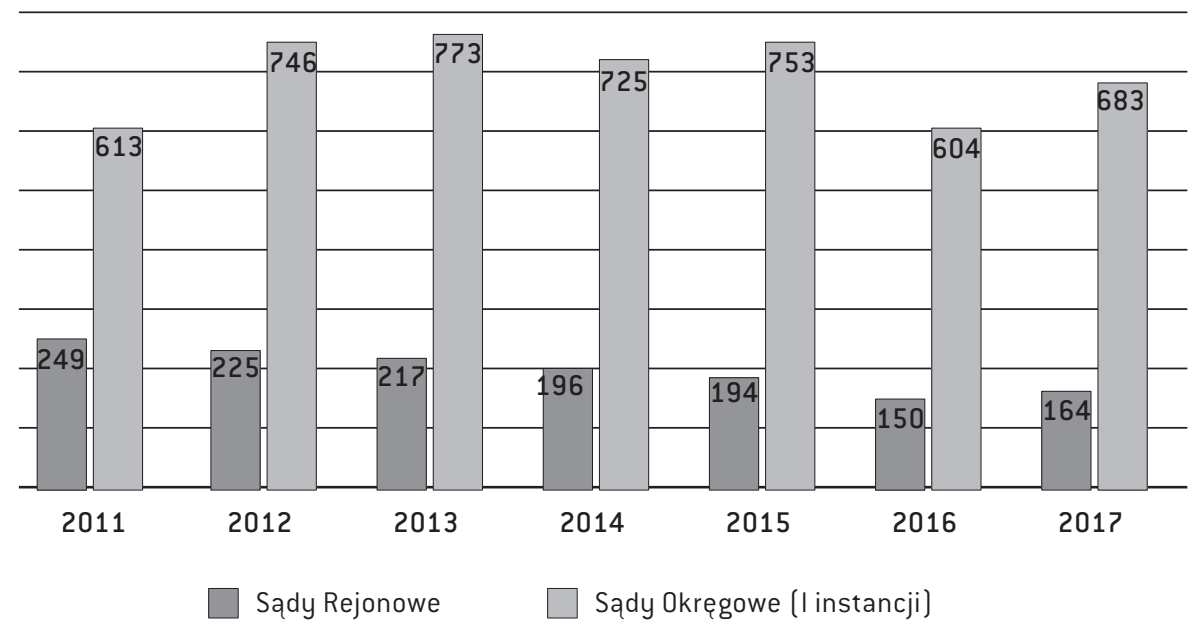

Źródło: opracowanie własne, na podstawie danych udostępnionych przez Ministerstwo Sprawiedliwości.

Widać więc, że liczba spraw odszkodowawczych rozpatrywanych przez sądy rejonowe, o mniejszej wartości przedmiotu sporu, zmalała wraz z wprowadzeniem alternatywnego systemu dochodzenia roszczeń. Może to świadczyć o tym, że postępowanie przed wojewódzkimi komisjami pełni funkcję alternatywy właśnie tylko w sprawach o mniejszej wartości przedmiotu sporu. Także tutaj należy wskazać, że w roku 2017 zanotowano wzrost ilości spraw wnoszonych do sądu względem poprzedniego roku. Brak danych za lata 2018-2019 nie pozwala jednak ocenić, czy był to jedynie jednoroczny wzrost, czy też początek tendencji wzrostowej, która mogłaby świadczyć o tym, że system przestał spełniać oczekiwania pacjentów także w tym zakresie. Za sukces systemu można za to uznać fakt, że jedynie niewielka liczba pacjentów odrzuca propozycję odszkodowania i decyduje się na wszczęcie postępowania sądowego po zakończeniu procedury przed wojewódzką komisją. Dane w tym zakresie wynikajajedynie z kontroli przeprowadzonej przez NIK, dotyczącej wniosków za lata 2014-2018. Na podstawie tych badań stwierdzono, że w przypadkach, w których wnioskodawcy zdecydowali się wycofać wniosek bądź odrzucili propozycję odszkodowania, jedynie 35 spośród 244 wnioskodawców $(13,1 \%$ ) weszło na drogę sądową.

\section{Wnioski}

Wdrożenie wojewódzkich komisji miało ułatwić dochodzenie przez pacjentów roszczeń wobec podmiotów leczniczych. W uzasadnieniu projektu nowelizacji przyjęto kilka podstawowych założeń. Pierwszym z nich było „zmniejszenie obciążenia sądów powszechnych postępowaniem w sprawie odszkodowań za błędy medyczne, przez zapewnienie alternatywnego postępowania przed wojewódzką komisja" ${ }^{16}$. Z danych wskazanych wyżej wynika jednak, że liczba spraw przed sądami

16. Uzasadnienie do rządowego projektu ustawy o zmianie ustawy o prawach pacjenta i Rzeczniku Praw Pacjenta oraz niektórych innych ustaw, VI Kadencja, druk sejm. nr 3488, s. 18. 
powszechnymi utrzymuje się na podobnym poziomie, niewielkie obniżenie dotyczy jedynie spraw przed sądami rejonowymi, czyli o mniejszej wartości. Założenie to nie zostało więc zrealizowane.

Po drugie, postępowanie przed wojewódzkimi komisjami miało stanowić alternatywę dla sądów powszechnych. Założenie to zrealizowano częściowo. Rzeczywiście, postępowanie nie zamyka drogi do dochodzenia roszczeń przed sądami powszechnymi. Jednakże wiąże się to ze zrzeczeniem się roszczeń powyżej kwoty przyjętej propozycji świadczenia ${ }^{17}$, a składane propozycje nie są wysokie (nie sięgają nawet wysokości limitów wynikających z u.p.p. i rozporządzenia kwotującego). Wiąże się to z wyrażaną w doktrynie wạtpliwością, czy system nie będzie używany jedynie w sprawach o stosunkowo niskiej wartości. Przeanalizowane dane nie pozwalają na to pytanie odpowiedzieć jednoznacznie. Z całą pewnością można jednak stwierdzić, że system nie stanowi alternatywy dla spraw, w których kwota potencjalnego odszkodowania jest wysoka.

Kolejnym z fundamentalnych założeń było zapewnienie szybkości postępowania (maksymalnie 4 miesiące). W doktrynie od samego początku budziło wątpliwości, czy taki termin będzie możliwy do dotrzymania, w szczególności w związku ze stosunkowo długim czasem na zajęcie stanowiska przez szpital bądź ubezpieczyciela. Analiza danych wskazuje, że rzeczywiście - w wielu przypadkach postępowanie nie zostaje zakończone w ustawowym terminie. Nie udało się zatem spełnić także tego założenia. Warto jednak zauważyć, że czas na zajęcie stanowiska przez szpital bądź ubezpieczyciela nie stanowi wcale czynnika, który odgrywa kluczową rolę w wydłużaniu postępowań. Tym, co wpływa na czas trwania w największym stopniu, jest powoływanie biegłych - analiza przedstawionych wyników jasno pokazuje, że w sprawach, w których biegli nie byli powoływani, średni czas trwania postępowania wynosił poniżej 4 miesięcy. W sytuacji powoływania biegłych wydłużał się średnio dwukrotnie.

Watpliwości budziło także, czy czas na wniesienie wniosku nie będzie zbyt krótki. Przeanalizowane dane nie dają odpowiedzi na to pytanie, prawdopodobnie w części z tego powodu, że przekroczenie terminu nie jest powodem do zwrotu wniosku. Nie ulega jednak wạtpliwości, że skoro czas na wniesienie wniosku jest krótszy od terminu przedawnienia, to w wielu przypadkach nieprzedawnionego roszczenia będzie można dochodzić jedynie przed sądem.

Kolejnym założeniem było oparcie ciężaru wypłacania świadczeń na ubezpieczycielach (co miało być krokiem w kierunku pełnego systemu No Fault Compensation). Wytycznej tej nie udało się zrealizować - szpitale często nie zawierają ubezpieczeń, tłumacząc się trudna sytuacją finansowa, co w konsekwencji doprowadza do tego, że to właśnie one, a nie ubezpieczyciel, wypłacają świadczenie.

\section{Podsumowanie}

Wskazane wyżej wyniki świadczą o tym, że system w swojej aktualnej postaci nie wypełnia należycie przewidzianej dla niego roli. Problem w tym zakresie zauważył także Rzecznik Praw Pacjenta, który pismem z dnia 13 listopada 2018 roku zwrócił się do Ministra Zdrowia z propozycjami zmian

17. Przy czym przedmiotowe zrzeczenie się roszczenia nie dotyczy roszczeń w zakresie szkód, które ujawniły się dopiero po dniu złożenia wniosku. 
Praktyczne problemy działania polskiego systemu alternatywnego dochodzenia roszczeń...

dla systemu ${ }^{18}$, których treści niestety nie udostępniono. Można jednak wskazać kilka obszarów, które warto usprawnić. Po pierwsze: przeanalizowanie regulacji udziału biegłych w sprawie. Połowa członków komisji musi posiadać wykształcenie z zakresu nauk medycznych. Wydaje się więc, że organ ten powinien znacznie rzadziej niż sąd potrzebować opinii biegłego, w związku z tym, że dany członek komisji będzie miał wiedzę z określonego zakresu. Jedną z metod, która mogłaby pomóc w tego realizacji, byłoby uregulowanie, że wśród członków komisji powinni znaleźć się lekarze określonych specjalizacji (tych, w których najczęściej potrzebne jest powołanie biegłego). Długi okres oczekiwania na decyzję biegłego może wynikać także z dużego obciążenia biegłych niektórych specjalizacji. Inną metodą na rozwiązanie problemu mogłoby więc być np. postulowane przez Tomasza Widłaka wprowadzenie możliwości wprowadzania biegłych ad hoc albo zasięgania opinii także konsultantów z innych województw ${ }^{19}$.

Kolejnym istotnym aspektem jest kwestia zrzeczenia się roszczeń w przypadku zaakceptowania propozycji świadczenia. Możliwym rozwiązaniem problemu niskich kwot faktycznie proponowanych byłoby wprowadzenie trybu pozwalającego na ustalenie wysokości odszkodowania już po wydaniu orzeczenia o zdarzeniu medycznym. Dzięki temu w sytuacji gdy fakt wystapienia zdarzenia byłby już przesądzony, pacjent i szpital bądź ubezpieczyciel mogliby ustalić satysfakcjonująca dla obu stron kwotę - np. w drodze arbitrażu albo mediacji. Warto byłoby także wprowadzić postulat doktryny o uregulowaniu instytucji współuczestnictwa w postępowaniu przed wojewódzką komisją. Niezależnie od tego, jakie rozwiązania spróbuje wprowadzić ustawodawca, nie ulega wątpliwości, że zmiany są konieczne dla zwiększenia wpływu systemu na sytuację pacjentów.

\section{Wykaz źródeł}

Dobkowska-Puławska I., Kazimierowicz R., Reczuch B., Pacjent i jego prawa w kontekście odpowiedzialności za błędy medyczne, [w:] Międzynarodowe standardy ochrony praw człowieka a doświadczenia Polski, Jaskiernia J., Spyszak K. [red.], Wydawnictwo Adam Marszałek, Toruń 2016. Glanc J., Orzekanie o zdarzeniach medycznych, [w:] Prawne aspekty reformy systemu ochrony zdrowia w Polsce, Bolt K. F., Sieniawska-Michalska D., Węgrzynowski B. [red.], Wydawnictwo Instytutu Studiów Europejskich, Gdynia 2013.

Informacja o wynikach kontroli: Pozasądowe dochodzenie roszczeń przez pacjentów, KZD.430.005.2018, nr ewid. 163/2018/P/18/057/KZD.

Kowalewski E, Śliwka M., Wałachowska M., Kompensacja szkód wynikłych z „błędów medycznych”. Ocena projektowanych rozwiqzań prawnych, „Prawo i Medycyna” 2010, nr 4.

Nesterowicz M., Wałachowska M., Odpowiedzialność za szkody wyrzqqdzone przy leczeniu w zwiqzku z nowym pozasqdowym systemem kompensacji szkód medycznych, [w:] Kompensacja szkód wynikłych ze zdarzeń medycznych - problematyka cywilnoprawna i ubezpieczeniowa, Kowalewski E. [red.], TNOiK, Toruń 2011.

18. Sprawozdanie Rzecznika Praw Pacjenta dotyczące przestrzegania praw pacjenta na terytorium Rzeczypospolitej Polskiej za rok 2018, s. 70.

19. T. Widłak, Wybrane problemy orzecznictwa o zdarzeniach medycznych - na przykładzie prac Wojewódzkiej Komisji ds. Orzekania o Zdarzeniach Medycznych w Gdańsku w 2012 r., „Wiadomości Ubezpieczeniowe” 2013, nr 2, s. 102. 
Serwach M., Ubezpieczenia z tytułu zdarzeń medycznych w teorii i praktyce, „Prawo Asekuracyjne” 2012, nr 4.

Sprawozdanie Rzecznika Praw Pacjenta dotyczące przestrzegania praw pacjenta na terytorium Rzeczypospolitej Polskiej za rok 2018.

Śliwka M., Wybrane czynniki determinujqce działalność wojewódzkich komisji orzekajqcych o zdarzeniach medycznych, „Prawo i Medycyna” 2012, nr 3/4.

Uzasadnienie do rządowego projektu ustawy o zmianie ustawy o prawach pacjenta i Rzeczniku Praw Pacjenta oraz niektórych innych ustaw, VI Kadencja, druk sejm. nr 3488.

Widłak T., Wybrane problemy orzecznictwa o zdarzeniach medycznych - na przykładzie prac Wojewódzkiej Komisji ds. Orzekania o Zdarzeniach Medycznych w Gdańsku w 2012 r., „Wiadomości Ubezpieczeniowe" 2013, nr 2.

Zduński l., Zdarzenie medyczne - bład medyczny w „nowej szacie”, [w:] Oblicza Temidy. Aspekty prawne ochrony zdrowia, Zgoliński I. [red.], Wydawnictwo Kujawsko-Pomorskiej Szkoły Wyższej, Bydgoszcz 2013.

\section{Effectiveness of the polish Alternative Patient Compensation System}

The Alternative Patient Compensation System has been operating in Poland for 8 years. There were high expectations upon its implementation, i.a. regarding the increase of compensation's effectiveness and quickness as well as the unburdening of court system. Doctrine had doubts about the System since its beginning. In order to compare the reality with expectations, data about the System was analysed. The outcome of anaylisis suggests, that the System does not operate at satisfactory level and does not fulfill its premises.

Key words: medical incidents, patients' rights, Committees for Adjudication of Medical Events.

MGR MATEUSZ KAŹMIERCZAK - prawnik, absolwent Wydziału Prawa i Administracji, Uniwersytet Gdański.

e-mail: mateusz.kazmierczak@route.com.pl 